\title{
( Tourism in Kuakata: A Curbed Rareness in aße Global Village
}

\section{Mohammad Abu Horaira}

Assistant Professor, College of Tourism and Hospitality Management (CTHM), IUBAT, Dhaka, BANGLADESH

*E-mail for correspondence: horaira@iubat.edu

\begin{abstract}
Kuakata, locally called as 'Sagor Konnya' (Daughter of the Sea) is located in the southernmost tip of Bangladesh and is one of the most rare tourism destinations having the exceptional view of the rising and setting of the crimson sun in the water of the Bay of Bengal. Perhaps that makes Kuakata one of the world's unique beaches. After reviewing the literature and different sources related to tourism, it is being found that there is very little attention given to Kuakata as an exclusive tourism destination. The paper is based on secondary data sources like-articles, journals, websites of the target tour operators and authorities. For the globalization of tourism, it is essential to provide background information about the destination to the international visitors and Bangladesh is far behind of it. The government, NTOs (National Tourism Organizations), local administration, owners of hotels and motels, private tour operators and travel agencies should work in an integrated approach which can create a positive impression about Kuakata in the tourists' mind and feels free to visit and recommend others.
\end{abstract}

Keywords: Kuakata, Rarest, Bay of Bengal, Beach, Tourism, Destination, Globalize, International Visitors, Bangladesh

\section{INTRODUCTION}

Kuakata, locally called as 'Sagor Konnya' (Daughter of the Sea) is located in the southernmost tip of Bangladesh and is one of the most rare tourism destinations having the exceptional view of the rising and setting of the crimson sun in the water of the Bay of Bengal in a calm environment. That perhaps makes Kuakata one of the world's unique beaches. Kuakata is the second largest sea beach in Bangladesh. The sea beach is enriched with diverse natural beauties. In spite of numerous potentialities, the tourism in Kuakata did not develop as much as it should be. It can be stated, the beauty of Kuakata is yet to be discovered by Bangladeshi and international tourists.

Bangladesh, a South Asian country crisscrossed with great streaming rivers, is indeed a land of green and natural beauty. Despite having lots of potentialities, the tourism industry of this country is growing very slowly. Forty-five years have passed since Bangladesh's tourism industry started its journey and however, its tourism is in a beginning stage compared to its neighboring countries. Bangladesh is still unknown as a tourist destination in the international arena.
As the world is opened up, tourism became an integral part of many countries' economic growth and mutual relations. Globalization increases wide-reaching technology, and the readability of fast, effective communication and consumption of popular products. Globalization links cultures and international relations on a variety of levels; economically, politically, socially and so on.

\section{LITERATURE REVIEW}

According to the researcher the conception of globalization is deployed across disciplines, across the world, across theoretical approaches, and across the political arena. Numerous scholars have rushed to claim the cliché of the day. A significant number of research institutes, degree program, and textbooks are now focusing on the problem. A number of new professional global studies associations have also come out since 2000. Several academics have even presented globalization as the focal point for an alternative model of social inquiry.

When academics illustrate globalization as internationalization, the term refers to a growth of transactions and interdependence between countries. From this perspective, a more global world is one where more messages, ideas, merchandise, money, investments, 
and people cross borders between national-state-territorial units. According to Paul Hirst and Grahame Thompson, globalization is an especial intense form of internationalization, so that the global is a particular subset of the international.

In accordance with the researchers, ideas of globalizationas-internationalization are attractive insofar as they entail a minimum of intellectual and political adjustments. Global relations of this kind can be examined on the same ontological and methodological grounds as international relations. Global Economics can be the same sort of enquiry as International Economics. The study of Global Politics need not differ substantially from traditional International Politics. Globalization-as-internationalization gives the comforting message that the new can be wholly understood in terms of the familiar.

Cultural heritage tourism is a fast-growing segment of the tourism industry, creating and sustaining jobs including providing opportunities for marginalized groups. It also strengthens social networks and cohesion as groups come together for a collective purpose.

UNESCO Universal Declaration on Cultural Diversity (2 November 2001) culture has been characterized as culture is a set of distinctive spiritual, material, intellectual and emotional features of society or a social group. It encompasses, in addition to art and literature, lifestyles, ways of living together, values systems, traditions and beliefs.

The importance of tourism, particularly of its role in economic growth, employment and attracting foreign exchange has been a contemporary issue for the analysts. Reality is that the tourists are the major source of foreign exchange via inbound tourism and it is one of the attractive goal for any country. Money is brought into the country by foreign visitors, and is taken out by local citizens visiting foreign destinations as tourists. The difference between inbound tourism expenditure and outbound tourism expenditure is known as the tourism trade balance with the rest of the world.

Transportation, tour operators, travel agents, and accommodation are mainly the sectors of tourism supply and these are examined and the importance of crosscountry integration between firms is highlighted. Tourism depends greatly on an authentic socio-cultural and an unrestrained natural environment. A discerning observer of the world tourism scene would sense a positive change that is gradually taking place in the order of preferences of the International and domestic tourist.

Sustainable tourism is the concept of visiting a place as a tourist and trying to make only a positive impact on the environment, society and economy.

World Tourism Organization (UNWTO) defines sustainable tourism as "Sustainable tourism development meets the needs of present tourists and host regions while protecting and enhancing opportunity for the future. It is envisaged as leading to management of all resources in such a way that economic, social, and aesthetic needs can be fulfilled while maintaining cultural integrity, essential ecological processes, biological diversity, and life support system" [WTO 1998: 19].

\section{Key Attractions Sites in KuAKata}

\section{Kuakata}

Kuakata, locally called as 'Sagor Konnya' (Daughter of the Sea) is located on the southernmost tip of Bangladesh in the Patuakhali district. It is about 320 Kilometers south of capital city Dhaka, and about 70 Kilometers from the Patuakhali district headquarters. Kuakata is an extensive sandy beach from where one can see both the sunrise and sunset from the same spot. This is one of the rarest characteristic of Kuakata and in the world; this type of opportunity is only present in Japan. The sandy beach of Kuakata is about $30 \mathrm{~km}$ long and $6 \mathrm{~km}$ wide.

The name Kuakata originated from the word 'Kua'-the Bengali word for "Well" which was dug on the sea seashore by the early Rakhine settlers in quest of collecting drinking water, who landed on Kuakata coast in the eighteenth century after being expelled from Arakan (Myanmar) by the Mughals. Afterward, it has become a practice of digging well in the locality of Rakhine tribes for drinking water.

The long strip of dark, marbled sand stretches sandy beach has gentle slopes into the Bay of Bengal, a typical natural setting for about $30 \mathrm{~km}$. Kuakata is also a sanctuary for migratory winter birds.

Kuakata is sacred pilgrimage for both Hindu and Buddhist communities. Innumerable religious devotees and local tourists arrive here at the festival of 'Rush Purnima' and 'Maghi Purnima'. The pilgrims take holy bath at the bay and participate in the traditional fairs on these two occasions. Besides, there is also 100 years old Buddhist Temple where one of the biggest statues of Gautama Buddha in South Asia and two wells of 200 years old are located.

\section{Kuakata Sea Beach}

The long and wide beach at Kuakata has a typical natural setting. This sandy beach has gentle slopes into the Bay of Bengal and bathing there is as pleasant as is walking or diving. Kuakata is truly a virgin beach, a beach of blue bay. Forest in the shoreline, boats with colorful sails, fishing, towering cliffs, surfing waves in the Bay of Bengal everything here touches and a feast for the eye. It exposes different attractiveness in different times.

During high tide, the Sea is full of water. There are waves to form Surf and foam broke into the shore. The waves will bring you onto the sand this moment, and the next moment it will move you onto the Sea. The beauty of the Sea is enhanced by several times during high tide. And during low tide the Sea becomes lifeless. It looks as if dried up. At the beginning of the high tide, water increases rapidly. 
During low tide, the sandy beach becomes artistic with snails and oysters.

\section{Gongamati Reserved Forest}

Gangamati Reserved Forest is an evergreen mangrove forest located on the eastern end of the beach of Kuakata. The Gangamati Reserved Forest is the additional part of the Sundarban forest. Gangamoti Reserved Forest protects the coast of Kuakata against tidal surges. The Gangamati Reserved Forest provides an opportunity to the visitors to experience a small mangrove forest. Different types of trees and plants like Keora, Gewa, Baen, Kankra, Goran, Hetal, Golpata and numbers of wild animals like wild boar, deer, monkey and different types of birds are found in the forest.

\section{Rakhine Polli}

Rakhine community has nearly 200 years old tradition in Kuakata. The largest Buddhist temple of Bangladesh is located $10 \mathrm{~km}$ away from the Rakhine Polli. The meditated idol of Gautam Buddha is 36 feet high and weight is approximately $1500 \mathrm{~kg}$. It is known that the beauty of the temple was followed by Chinese Architecture. The people of the Rakhine community, stranded in Arakan State, migrated to the sea under the leadership of their King Mong and then settled themselves in Chittagong and later in the forests of Patuakhali district and built their habitat in their tradition and culture. The government gave them land for making their village.

Rakhine community mostly follows "Buddhism" and "Buddha Purnima" is their most important spiritual festival. Each of their house has an own embodiment. Men are usually engaged in agriculture and the women are in making handicraft. They make Lunge, Scarf, and Shawl etc. and sell in the women operated market named "Rakhine Mohila Market".

\section{Sima Mondir}

This Buddhist Temple is the holy and oldest monastery of the Buddhist community. There is a big statue of Gautam Buddha and is recognized as the second largest embodiment of Gautam Buddha in South Asia. The people of the Rakhine community regard it as a God and worship it.

\section{Coconut Grove and Jhaubon}

The coconut grove was created on 200-acre areas around sea beach in1960s. But for the continuous breaking of the beach, a part has already been eradicated into the sea. At the east side of the grove, there is a beautiful Jhaubon. During the dusk and under moonlight, it looks wonderful and the continuous whizzing sound of Jhaubon creates an echo of serenity to visitors at the daytime.

\section{Fatrar Char}

At the west side of the beach, there is a small island named Fatrar Char, a beautiful mangrove forest. Fatrar Char is the part of the Sundarbans where having the existence of different mangrove trees like Keora, Gewa, Goran,
Golpata, etc. Many birds and animals like monkeys, pigs etc are found in this forest.

\section{Lebur Char}

Lebur Char is an attractive place locally named as Lembur Chor or Nembur Char located about five kilometers east of Kuakata beach. There are several species of trees like Keora, Gewa, Goran, Karei, Golpata, etc. in the area of 1000 acres. Earlier, it was a part of Sundarbans, but it is now totally isolated from the Sundarbans range.

\section{Ras Mela}

Ras Mela is the principal festival and fair of the Manipuri community; it is also being observed by Hindu community at different places. It is held on the night of the full moon in Kartik-Agrahayan at Kamalganj in Maulvi Bazar, at Dublar Char in the Sundarbans and on the Kuakata beach in Patuakhali. The festival was being sonamed because it has evolved from the spiritual Rasalila (love-play) of Radha and Krishna at Vrindavan. On the occasion of Ras Purnima, devotees take a bath in the sea with hope to cleanse of their sins, right, and prayers are offered at the sea beach during sunrise. The three-day celebrations began with devotees taking a dip in the Bay at dawn after the full moon, known as Ras Purnima. The devotees believe that the bath would wipe out all their sins. During the festival people of Hindu community participated in various activities like Kirton (religious song), religious discussion, puja of Lord Krishna and Radha and bathing in the Bay. A lot of tourists also gathered at the sea beach to enjoy the 150-year-old Mela.

\section{Shutki Polli}

Shutki (dry fish) Polli is situated $4 \mathrm{~km}$ west of Kuakata. Fisher catch many kinds of sea fish from the sea during the year but mainly which are caught in the winter season, are sun-dried in process. The "Shutki" is supplied in many places of our country, mainly in Dhaka. The people who like to eat "Shutki" can have the opportunity to see the process of drying fish.

\section{BARRIERS TO KUAKATA TOURISM}

Tourism can play a meaningful role in community development, but the capability of the government, the private sector, and the local people for managing and developing tourism has been questioned by various researchers and scholars. The development of tourism is related to the local-level infrastructure, regional and national level framework, global network, and on the issues surrounding the utilization of natural resources and the conservation of culture, heritage, and social values. There is no such visible tourism framework has been established yet to utilize Kuakata as a rare tourism destination in the global village by Bangladesh Government. As a developing country, Bangladesh is moving towards facing challenges of globalization. Its tourism appears to have suffered mostly due to inadequate 
infrastructure, insufficient transport facilities, and absence of facilities at destinations (Hossain, 1999). Some communities have been successful in developing tourism while others have not. It has been interesting to learn how some developing countries, whose primary occupation is farming, have been able to embrace new economic movement sustainability while still maintaining the community's identity and way of life.

\section{Methodology}

The study is based on secondary data analysis. The data have been collected from different published articles, reports, Bangladesh Parjatan Corporation (BPC), Travel and Tourism Council (WTTC), newspaper articles, websites, etc. An explanation of the overall study has established the tourist attractions of the place and given the guidance towards the utilization of the rareness. And this study experiences will provide the answers to many of the questions raised by the study.

- To know about the current status and prospect of Kuakata as a rare tourism destination

- To identify the major attractions of Kuakata

- To recognize the barriers to developing the tourism in Kuakata

- To provide some suggestions for the development of Kuakata as a rare tourism destination

\section{DATA ANALYSIS}

Different sources of secondary data were used for the study like-articles, journals, websites of the target tour operators and authorities. The official website of BPC (Bangladesh Parjatan Corporation) was the most important source of secondary data.

Geo-tourism is a kind of ethical tourism which is aimed to sustain and enhance the authentic geographical character of a place-its environment, culture, heritage, aesthetics and wellbeing of the residents of that particular area. According to Worldwatch Institute, ecotourism, geotourism, and pro-poor tourism are among the increasingly popular niches in the travel industry that aim to address consumers' ethical concerns (Worldwatch Institute, 2005).

According to researchers, in the western media, Bangladesh is often represented as an underprivileged, underdevelopment country that is destined to fight with natural disasters frequently. The country has had the image of unprivileged people, underdevelopment infrastructure and vulnerable to the natural disasters. But in the context of Bangladesh, nature has compensated all those natural disasters with some unique blessings and that has been behind the curtain over the ages. The country has the world largest natural sandy sea beach, one of the largest mangrove forests, Kuakata Sea Beach which is one of the very rare beaches of the world where the tourists can view both sunrise and sunset. Besides, Bangladesh has a rich tradition, historical achievements, eye-catching architectures, ancient and marvelous establishments, historical and spiritual sites, lush greenery surfaces, diversified landscapes, numerous archaeological sites, a place of a good number of tribes with much colorful life. All these things have made Bangladesh an attractive tourist destination. (BPC, 2012)

\section{DISCUSSION AND RECOMMENDATION}

Promotion plays a significant role in tourism exploration. The success of tourism industry of a particular country is widely associated with the level of promotional activities which a country's government and private tourism organizations usually undertake. The tourism promotion in Bangladesh is far behind from reaching its goal; as a result, Bangladeshi tourism market has been a failure to attract more foreign tourists. The main reason is that there has always been lack of promotional activities to capture the world tourism market. Both the private and public tour operators of Bangladesh have the resource constraints and cannot afford the sufficient budget for the promotional purpose. In addition to that, the tour operators have lack of knowledge and idea about tourism promotional activities and as a result; they cannot create and offer attractive tour packages with international level of exposure, and lose their potential tourism market share. The operators only prefer the local media to promote tourism which is not effective enough for the tourism industry where the extent of the target market is large and diversified and the potential customers are in the different parts of the world. In addition to that, poor quality of promotional materials, inadequate media coverage, perceived negative image to the international tourists imposed by international media and news of natural disasters of Bangladesh on world media overshadowed the tourist attractions of the country in international arena. The government must take steps for highlighting Kuakata to domestic and international tourists through proper marketing strategies. NTOs (BPC, BTB) should be given their concentration to promote Kuakata through electronic media, websites, YouTube or social media, local and foreign tour operators, tourism agencies, Bangladeshi foreign missions, travel writers, etc.

The economic impact or contribution of travel and tourism of Bangladesh mainly comes through the revenue generated from the industry as well as from its contribution to GDP. A noticeable economic momentum of Bangladesh also comes through the mobility of money by employing a large number people in tourism as the sector is mostly laborintensive and Bangladesh has a supply of labors. Besides, Bangladesh earns a good amount of foreign currencies every year from the sector (BPC, 2012).

\section{CONCLUSION}

According to the World Travel \& Tourism Council (2006), globalization of capitalism, movement of populations, and advances in transportation and communication technology helped to develop tourism into one of the 
World's largest industries over the 20th century. Tourism is considered as an effective vehicle for the economic development of many countries in the world. UNWTO (2008) reported that some countries including Bangladesh, have the significant source of income, employment, and investment. Bangladesh is endowed with resources and the potential for tourism industry. As a developing country, Bangladesh is moving towards facing challenges of globalization. Its tourism appears to have suffered mostly due to inadequate infrastructure, insufficient transport facilities, and absence of facilities at destinations. Bangladesh also suffers from its image problem. Many foreigners believe that Bangladesh is a politically unstable country. As a developing country, tourism industry can play an important role to boost up the economy of Bangladesh. Though Bangladesh has a lot of opportunities to gain profit by offering this sea beach to local and foreign tourists, there are some problems which are made obstacles to boost up tourism in Kuakata. Bangladesh Government should take realistic initiatives to develop service distribution system and long-term plan for Kuakata as a dream destination. Therefore, government, NTOs (National Tourism Organizations), local administration, owners of hotels and motels, private tour operators and travel agencies should work in an integrated approach which creates a positive impression about Kuakata in the tourists' mind and feels free to visit and recommend others.

\section{REFERENCES}

Allee, J. \& N. Kotler, "Strategic Tourism Marketing Workbook. Tourism Destination Management and Marketing Program." Washington, DC: The George Washington University, 2003.

Business Promotion Council (BPC) Newsletter-2012

Chang TC., "Local uniqueness in the global village: Heritage tourism in Singapore." Wiley Online Library, 1999.
Hirst, P., and Thompson, G., "Globalization in Question: The International Economy and the Possibilities of Governance." Cambridge: Polity, 1999.

Hossain, Md. Afjal, "Marketing of Tourism Industry in Bangladesh: An Empirical Study of Performance and Strategies." Ph.D. Thesis, University of Pune, India, 1999.

Hossain, S.E., "Future of Tourism in Bangladesh-Ecotourism and e-tourism." Proceedings of International Seminar on Development of e-Tourism Technologies in Islamic Countries. Islamic University of Technology, Gazipur, Bangladesh, 2008.

Kotler, P., Bowen, John T., \& Makens, J., "Marketing for Hospitality and Tourism." USA: Pearson. 2010.

Mittelman, J.H., "Globalization: An Ascendant Paradigm?." International Studies Perspectives, vol. 3, no. 1, February 2002.

Poletto, D., "Territorial Diagnostic of the Tara River Basin Biosphere Reserve and the Durmitor World Heritage Site in Montenegro." UNESCO-BRESCE, 2008.

Roy Sanjay C., Roy Mallika, "Tourism in Bangladesh: Present Status and Future Prospects," International Journal of Management Science and Business Administration, 2015.

Sinclair, M. T., "Tourism and economic development: A survey.", The Journal of Development Studies, November 2007.

UNWTO Tourism Highlights, 2008 Edition, https://www.eunwto.org/doi/book/10.18111/9789284413560

World Trade Organization (WTO), Annual Report 1998

World Travel and Tourism Council (WTTC): "The Economic Impact of Travel and Tourism 2014." Annual report-2014.

\section{Websites}

http://www.parjatan.gov.bd/site/page/705a1556-16f3-410f8e04-efbdc2d2b3b1/Kuakata accessed on 21.04.2018

http:/ / www.tugberkugurlu.com/archive/definintion-oftourism-unwto-definition-of-tourism-what-is-tourism accessed on 20.04.2018 
How to Cite: Horaira, M. (2018). Tourism in Kuakata: A Curbed Rareness in Global Village. American Journal of Trade and Policy, 5(2), 67-72.

\section{SOCIAL SCIENCE RESEARCH NETWORK \\ 2171 Monroe Avenue, Suite 203, Rochester, NY 14618, USA \\ http://www.ssrn.com/en/}

SSRN Link: http://www.ssrn.com/link/American-Journal-Trade-Policy.html 